\title{
Effect of different cell disruption methods on lipid yield of Schizochytrium sp.
}

\author{
Mustafa Hac İsa ${ }^{1}$, Cansu Metin ${ }^{1}$, Ertan Ercan ${ }^{2}$, and Yunus Alparslan ${ }^{2}$ \\ ${ }^{1}$ Muğla Sitkı Koçman University \\ ${ }^{2}$ Affiliation not available
}

June 17, 2021

\begin{abstract}
In this study, it was investigated to increase the lipid yield of the microalgae Schizochytrium sp., by applying different cell disruption methods. Therefore, acid treatment with $\mathrm{HCl}$, osmotic shock, enzyme applications and ultrasonic homogenizer were tried in this algae species combined with the Bligh and Dyer and Soxhlet methods as an alternative to classical lipid extraction methods. As a result of the study, the highest lipid value $(21.72 \pm 0.74 \%)$ was obtained in enzyme application with Bligh and Dyer method (BDE). The cell disruption processes increased the lipid yield compared to the control groups. The highest PUFA DHA was found in the range of $4.58 \pm 2.44-19.25 \pm 0.09 \%$, and the highest value was observed in the BDE group. Highest SFA was palmitic acid. Effective results were observed in the Bligh and Dyer applied groups in terms of both total lipid and total fatty acids. In cell disruption methods, particularly in enzyme and $\mathrm{HCl}$ extraction, good results were obtained in terms of fatty acids. The highest total fatty acids and the highest lipid content were detected in the Bligh and Dyer enzyme (BDE). Enzyme applications are also advantageous because of being environmentally friendly. Lipid health indices such as n-6/n-3, PUFA/SFA, Atherogenicity index (AI), Thrombogenicity index (TI) and hypocholesterolemic/hypercholesterolemic ratios $(\mathrm{HH})$ were almost favorable. With this study, an appropriate lipid extraction methods were determined to provide an economical and environmental friendly suggestion for future studies to be used in areas such as food, feed and cosmetics.
\end{abstract}

\section{Introduction}

Microalgae are photosynthetic microorganisms capable of converting carbon dioxide and water into organic macromolecules such as lipids, polysaccharides and proteins under light conditions (Cho et al., 2013). They can be produced year-round, depending on the climate and solar radiation, grow at very high rates, and in a wide variety of water sources (fresh, brackish water, seawater and wastewater) (Souza Silva et al., 2014). They can also be easily harvested and can be cultivated under various conditions (Ju et al., 2020). Therefore, the microalgae have an extraordinary biotechnological potential as an alternative to non-renewable resources due to production of natural substances and biomaterials that can be used in various industrial applications (Neto et al., 2013). The lipid content of microalgal cells range from $2 \%$ to $77 \%$ depending on the species' environmental and growth conditions (Souza Silva et al., 2014).

Microalgae have high and good quality lipids, especially long-chain unsaturated fatty acids such as linolenic acid, arachidonic acid, eicosapentaenoic acid (EPA) and docosahexaenoic (DHA), has been a remarkable issue for many years. Adequate DHA intake protects against many noncommunicable diseases such as diabetes, cardiovascular and neurodegenerative diseases, cancer and schizophrenia (Wang et al., 2020). Microalgal lipids can be produced safely and stably using pure cultures, and the obtained products have potential to use in high-value-added industries, such as medicine and cosmetics (Ju et al., 2020).

Heterotrophic Crypthecodinium, Schizochytrium and Ulkeniaspecies are considered as the first commecialized species that has been used for food, feed and biodiesel production, due to their high fat content. Schizochy- 
trium sp. is a marine algae, which is important in terms of DHA, closely related to diatoms, single-celled, thraustochytrid and commonly found in sea waters, estuaries and sediments (Borowitzka, 2013). Schizochytrium sp. is a globose and pale-yellow marine microalga that possesses a thallus thin wall. This is of great industrial interest because of producing metabolites (Ortega-Berlanga et al., 2018). This marine organism has a relatively high fat content. Schizochytrium oil that is rich in DHA and EPA, also took its place in the market (Borowitzka, 2013).Schizochytrium is considered to be a promising alternative and excellent DHA source (Wang et al., 2020) and it is accumulated intracellular DHA accounts for $30 \%-40 \%$ of its total lipid content (Chang et al., 2020). There are no reports of this organism producing toxic chemicals or being pathogenic (Fedorova-Dahms et al., 2011).

Direct lipid extraction from wet biomass is not easy because algal cell walls, are mainly composed of cellulose, are very durable and difficult to break (Lee and Han, 2015). The lipid yield is mainly affected by the rigidity of the microalgal cell wall. Due to their complex structure, the tensile strength of microalgal cell wall is estimated to be higher than plant's cell wall (Nagappan et al., 2019). Since the thick cell wall of microalgae, which prevents to obtain lipids, it is necessary to use different methods other than the traditional mechanical press to obtain high efficiency in lipid extraction. An ideal solvent plays an important role in lipid extraction (Neto et al., 2013). Solvents including hexane, chloroform, butanol, ethanol, methanol and diethyl ether have been widely reported for lipid extraction from microalgae (Nagappan et al., 2019). Fragmentation methods aim to increase the efficiency of obtaining lipids from microalgae by using mechanical and non-mechanical techniques. Mechanical techniques include compression, high-pressure homogenization, ultrasonic bath, autoclave, bead mill, microwave and magnetic stirring, while non-mechanical techniques include chemical fragmentation and osmotic shock and enzymatic hydrolysis (Neto et al., 2013; Zhang et al., 2018). To get higher lipid yield and quality with lower production costs from microbial cells, a suitable cell disruption method is required.

The objective of the present study was to increase the lipid yield ofSchizochytrium sp ., which has high amounts of valuable fat and fatty acids, but obtained low lipid yield due to the fact that the cell walls are not broken down by conventional lipid extraction methods. In addition to the classical Bligh and Dyer and Soxhlet methods; treatment with $\mathrm{HCl}$ as a solvent, osmotic shock as a non-mechanical process, ultrasonic homogenizer as a mechanical process and enzyme applications as a biological process were compared.

\section{Material and Methods}

Schizochytrium sp. micro algae species was used as the study material. Spray-dried samples were obtained from Marin Biotechnology Products and Food Industry (Aydın/Turkey).

In order to increase the lipid yield of this algae, 4 different cell disruption methods were tried; treatment with $\mathrm{HCl}$ in the reflux, osmotic shock, enzyme and ultrasonic homogenizer. After each cell disruption method, classical method of Bligh and Dyer (1959) and Soxhlet extraction methods of AOAC (2006) were applied for total crude lipid. Bligh and Dyer (1959) and AOAC (2006) Soxhlet methods applied alone were accepted as control groups. The groups were coded as follows; Bligh and Dyer and Soxhlet groups; control (BDC and $\mathrm{SC}$ ), osmotic shock (BDOS and SOS), enzyme (BDE and $\mathrm{SE}), \mathrm{HCl}(\mathrm{BDHCl}$ and $\mathrm{SHCl}$ ), ultrasonic homogenizer (BDUH and $\mathrm{SUH}$ ); respectively. In each method, $2 \mathrm{~g}$ of dry algae samples were used. Each analysis was carried out in three parallel.

\section{Total (crude) lipid}

\section{Bligh and Dyer method}

Methanol+chloroform (1:2) (40 mL) mixture was added to the algae sample and homogenized. Then, 20 $\mathrm{mL}$ of $0.4 \% \mathrm{CaCl}_{2}$ solution was added onto these samples. The samples filtered on a filter paper and then filtered into the tared balloons kept in the oven at $105{ }^{\circ} \mathrm{C}$ for 2 hours. These balloons were kept in a dark environment overnight and the upper layer consisting of methanol+water was separated with the help of a separation funnel. Chloroform from the chloroform + lipid part in the solution remaining in the flask was evaporated using a rotary evaporator (Heidolph) with the help of a water bath at $60{ }^{\circ} \mathrm{C}$. 


\section{Soxhlet method}

Samples were placed in cartridges and put into the VELP SCI SER 148-Italy brand automatic soxhlet mechanism and hexane $(60 \mathrm{~mL})$ was used for lipid seperation. Process of immersion for 90 minutes at 180 ${ }^{\circ} \mathrm{C}$, washing for 120 minutes at $80 @ \mathrm{C}$, and finally recovery for 8 minutes was carried out in the device (AOAC, 2006).

\section{Cell disruption methods}

\section{$\mathrm{HCl}$ extraction}

In the application of $\mathrm{HCl}$ as solvent, the algae: $\mathrm{HCl}(3 \mathrm{~N})(1: 40)$ was boiled at reflux for 1 hour (acid hydrolysis step). The sample was passed through filter paper and washed with $500 \mathrm{~mL}$ of water and filtered. After filtering, the filter paper was dried for 1 hour in an oven at $103{ }^{\circ} \mathrm{C}(\mathrm{AOAC}, 2005)$. The dried samples were continued with Bligh and Dyer and Soxhlet methods.

\section{Osmotic shock extraction}

In the osmotic shock method, the dry algae sample was kept in a $10 \%$ saline solution for 2 days at a ratio of algae:salt water (1:10) (Prabakaran and Ravindran, 2011), lipid extraction was continued with Bligh and Dyer and Soxhlet methods.

\section{Enzyme extraction}

In the enzyme application, $10 \%$ cellulase enzyme was applied to the dry algae sample with the ratio of 1:10 (algae:enzyme) and kept in the oven at $55{ }^{\circ} \mathrm{C}$ for 2 days (Liang et al., 2012). Afterwards, the lipid extraction was continued with Bligh and Dyer and Soxhlet methods.

\section{Ultrasonic homogenizer extraction}

Solvent (chloroform:methanol 2:1) was added to the dry algae sample and then homogenized in an ultrasonic homogenizer (Bandelin UW 3200/20 kHz) for 20 minutes (Byreddy et al., 2015). The lipid extraction was continued with Bligh and Dyer and Soxhlet methods.

At the end of each disruption method, the beakers in which lipid accumulates, were kept in the oven at 60 ${ }^{\circ} \mathrm{C}$ in order to remove the remaining solvent, then they were kept in a desiccator for 30 minutes and their final weighings were taken after cooling.

$$
\text { Crude lipid } \%=(\text { Final Weight }- \text { Initial Weight }) / \text { Sample Weight x } 100
$$

\section{Fatty Acids Methyl Esters (FAME) Analysis}

The methyl esters of lipid from the samples were prepared by trans methylation according to the method described by Ichihara et al. (1996) with a minor modification. Briefly, $25 \mathrm{mg}$ of extracted oil was dissolved in $2 \mathrm{~mL}$ isooctane, followed by $4 \mathrm{~mL}$ of $2 \mathrm{M} \mathrm{KOH}$ (in methanol) addition. Then, the tube was vortexed for $2 \mathrm{~min}$ at room temperature. After centrifugation at $4000 \mathrm{rpm}$ for $10 \mathrm{~min}$, the isooctane layer was taken for Gas chromatography analysis.

Gas Chromatography (GC) Conditions: The fatty acid methyl esters were analyzed using Gas chromatograph of Agilent Technologies model 7820 equipped with a flame ionization detector (FID) and fitted with a HP-88 capillary column (60 m x $0.25 \mathrm{~mm} \times 0.25 \mu \mathrm{m}$ thickness). Helium was used as the carrier gas at a constant pressure of 16 psi. Injection port was maintained at $220^{\circ} \mathrm{C}$, and the sample was injected in split mode with a split ratio of $50: 1$. Detector temperature was $280{ }^{\circ} \mathrm{C}$. Column temperature was started at $175{ }^{\circ} \mathrm{C}$, and then programmed at $3{ }^{\circ} \mathrm{C} / \min$ to $220{ }^{\circ} \mathrm{C}$, ramped at $1{ }^{\circ} \mathrm{C} / \min$ to $220{ }^{\circ} \mathrm{C}$, and held for $10 \mathrm{~min}$. The total running time was 26 minutes. Helium was used as the makeup gas at a constant flow of $40 \mathrm{~mL} / \mathrm{min}$, and hydrogen and dry air were used as detector gases. Identification of fatty acids was carried out by comparing sample FAME peak relative retention times with those obtained for Supelco standards (Supelco 37 Compounds FAME mix $10 \mathrm{mg} / \mathrm{mL}$ in CH2 Cl2-47885 U, Supelco 1819-1 Ampule FAME mix C4-C24). Results of each fatty acids were expressed as FID response area relative percentages of the total fatty acids determined (ISO, 1990). 


\section{Lipids nutritional quality indices (LNQI)}

The data from fatty acids composition analysis were used to determine the nutritional quality of the lipid fraction by means of three indices using the following calculations (Prato et al., 2019):

Atherogenicity index

$\mathrm{AI}=(12: 0+4 \times 14: 0+16: 0) / \mathrm{MUFA}+\mathrm{PUFA}$

Thrombogenicity index

$\mathrm{TI}=(14: 0+16: 0+18: 0) /[(0.5 \times \mathrm{MUFA}+0.5 \times \mathrm{n} 6 \mathrm{PUFA}+3 \times \mathrm{n} 3 \mathrm{PUFA}+(\mathrm{n} 3 / \mathrm{n} 6)]$

Fatty acids hypocholesterolemic/hypercholesterolemic ratios

$\mathrm{HH}=(18: 1 \mathrm{cis} 9+18: 2 \mathrm{n} 6+20: 4 \mathrm{n} 6+18: 3 \mathrm{n} 3+20: 5 \mathrm{n} 3+22: 5 \mathrm{n} 3+22: 6 \mathrm{n} 3) /(14: 0+16: 0)$

Statistical Analysis

All experiments were carried out in triplicate and the results were reported as the mean and standard deviation of these measurements. Statistics on a completely randomized design were performed with the analysis of variance (ANOVA) procedure in SPSS (Version 21, SPSS Inc., Chicago, IL, USA) software. Tukey's multiple range test $(P<0.05)$ was used to detect differences among mean values of all test intervals.

\section{Results and Discussion}

\section{Crude lipid}

In the present study, lipid yield of the treatment with $\mathrm{HCl}$ in the reflux, osmotic shock, enzyme and ultrasonic homogenizer cell disruption methods with Bligh and Dyer and Soxhlet crude lipid methods are shown in the Fig. 1. Bligh and Dyer and Soxhlet lipid extraction methods, which were not applied any disruption processes were accepted as control groups. Lipid ratio of the control groups Bligh Dyer control (BDC) and Soxhlet control (SC) was determined as $18.87 \pm 0.4 \%$ and $5.54 \pm 0.08 \%$, respectively. Lipid ratio of Bligh and Dyer applied groups BDOS, BDE, BDHCl and BDUH was found as $20.92 \pm 1.87 \%, 21.72 \pm 0.74 \%$, $19.38 \pm 1.20 \%$ and $14.52 \pm 0.36 \%$, respectively. The lipid yield of Soxhlet method applied groups SOS, $\mathrm{SE}, \mathrm{SHCl}$ and $\mathrm{SUH}$ groups was found as $8.21 \pm 1.60 \%, 11.98 \pm 1.41 \%, 12.26 \pm 0.15 \%$ and $14.70 \pm 0.3 \%$, respectively. The highest lipid value was detected in the BDE group $(P<0.05)$ and followed by BDOS, the difference between these groups was found to be statistically insignificant $(P>0.05)$. The lowest value was found in the SC group $(P<0.05)$. The highest lipid value in the Soxhlet applied groups was found in the SUH group with $14.70 \pm 0.30 \%$. It was found statistically significant from other Soxhlet applied groups $(P$ $<0.05)$. Comparing the BDC and SC control groups showed all cell disruption methods were able to disrupt algal cells, although the lipid although lipid yield showed differences $(P<0.05)$.

Fig. 1 Lipid yield of different cell disruption methods

Difficulties arise in obtaining lipid due to the cell walls of microalgae. For this reason, in this study, lipid was obtained fromSchizochytrium sp . with the $\mathrm{HCl}$ treatment, osmotic shock, enzyme and ultrasonic homogenizer cell disruption methods to increase the lipid yield to be used for feed, food and cosmetic raw material for future studies. In our study, it was observed that the cell disruption methods increased the lipid yield compared to the control groups. The highest lipid yield was detected in the BDE group $(21.72 \pm 0.74 \%)$. Higher results were obtained in the Bligh and Dyer crude lipid method compared to Soxhlet. Lipid ratio of BDOS (20.92 $\pm 1.87 \%)$ group also followed the BDE group lipid ratio and there was no statistically significant difference $(P>0.05)$. In the Soxhlet groups, the highest lipid value was found in SUH group $(14.70 \pm 0.3 \%)$, followed by the $\mathrm{SHCl}(12.26 \pm 0.15 \%)$. The difference between these two groups was statistically significant $(P<$ 0.05). When our results were compared, it was observed that the lipid yield was lower in the Soxhlet applied groups, and the laboratory scale applicability of the Bligh and Dyer method was more appropriate. Araujo et al. (2013) reported that the Soxhlet extraction mechanism is mainly diffusion and the procedure does not involve mechanic disruption to the biomass. Their results showed that simply diffusion of lipids through the 
cell membrane is a slow process and results in low yield of lipid. Similar with the study of Araujo et al. (2013), low results were obtained in the Soxhlet method compared with the Bligh and Dyer method, in our study. In the literature studies, different applications such as autoclave, bead-beating, microwave, ultrasonication and osmotic shock were applied to increase the lipid amount of microalgae. Positive results were obtained with different mechanical applications using different solvents, however environmentally friendly applications such as use of enzymes is promising. Byreddy et al. (2015) studied cell disruption methods to increase the efficiency of lipid extraction ofSchizochytrium sp. using different solvents in their study. The maximum yield was obtained from the chloroform:methanol (2:1) solvent. Chloroform:methanol (2:1) was used in our study with reference to Byreddy et al. (2015). Liquid nitrogen grinding, osmotic shock, vortexing, water bath and sonication were used in their study to increase the efficiency of lipid extraction. In the osmotic shock application, the highest efficiency of lipid was obtained forSchizochytrium sp. as $48.7 \%$, while lipid yield of the control group was below $10 \%$, in their study. In our study, there was an increase in lipid yield in cell disruption methods compared to the control group.

Araujo et al. (2013) declared the Bligh and Dyer method assisted by ultrasound resulted in the highest extraction of lipid from C. vulgaris $(52.5 \%)$ and lipid yield with Soxhlet method was obtained quite low $(1.8 \%)$. Lee and Han (2015) applied hydrodynamic cavitation with sulfuric acid for different durations in Nannochloropsis salina species to increase lipid yield. While sulfuric acid concentrations were $0.1 \%$ and $2 \%$ lipid contents were determined as $21.7 \%$ and $45.4 \%$, respectively. Lipid yield was increased with the increase of acid concentration and time. In our study, the lipid yield of $\mathrm{HCl}$ disruption combined with Soxhlet and Bligh and Dyer methods, was obtained respectively as; $12.26 \pm 0.15 \%$ and $19.9 \pm 1.20 \%$ and an increase occurred compared to the control group. Although its high efficacy for disrupting microalgal cells, sulfuric acid treatment is not appropriate for use in a microalgal biorefinery because of destroying the activity of valuable cellular components (such as protein and pigment) (Halim et al., 2012). Liang et al. (2012) studied to increase lipid yield of Chlorella vulgaris , Scenedesmus dimorphusand Nannochloropsis sp. by enzyme (cellulase, neutral protease and alkaline protease) and sonication treatment. The highest lipid yield was obtained as $49.82 \%$ in the combined sonication-enzyme treatment. Lipid yield of control group increased from $15.11 \%$. A single method of extraction cannot be sufficient to reach the maximum yield. Combination of pretreatment methods with different solvents increase lipid yield of the algae (Mubarak et al., 2015). Studies have also demonstrated that lipid extraction efficiency of enzymatic treatment is higher than the mechanical methods including microwave and ultrasonication. The yield of lipid achieved through enzymatic hydrolysis depends on the type of enzyme used, $\mathrm{pH}$, temperature and microalgal type (Nagappan et al., 2019). In our study, the highest amount was observed in enzyme application and in order to get better results, the enzyme was treated at $55 \mathrm{degC}$, which is the optimum temperature for the cellulase enzyme. Taher et al. (2014) in their on extracting lipid with enzyme (lysozyme and cellulase) from Scenedesmus sp., declared Soxhlet method, the lipid value was $4 \%$ in the control group without any application. The highest value was obtained with lysozyme (16.6\%) followed by the cellulase enzyme (15.4\%). Algal cell disruption methods to increase lipid extraction from microalgae depends on species, age of the culture and composition of cell wall. Only few mechanical methods such as application of enzymes/chemicals either or alone can be considered for industrial applications. Osmotic shock method can also be applied industrially for lipid extraction, because of reducing energy consumption and production cost (Byreddy et al., 2015). Although acid treatment process is efficient in cellulose degradation, sulfuric acid is toxic and corrosive, so this process is not recommended (Taher et al., 2014). As a result in our study, the best results were obtained in the enzyme applied groups, but also, osmotic shock, ultrasonic homogenizer increased lipid yield compared to the control group, and these methods can be evaluated positively on an industrial scale.

\section{Fatty acids}

The fatty acid results of the sample groups treated with different lipid extraction methods from Schizochytrium sp. are shown in Table 1 and Table 2. Palmitic acid (16:0) was the highest fatty acid in the saturated fatty acid group. Palmitic acid was detected in the range of 54.90 +- $0.17-74.86+-2.88 \%$ in the sample groups and the highest value was in the SC group $(P<0.05)$. The highest saturated fatty acid after palmitic acid was miristic acid (14:0) in the range of $4.16+-0.01-5.55+-0.15 \%$. Among the 
monounsaturated fatty acids, miristoleic acid (14:1) was found in the highest amount $(4.29+-0.95-5.86+-$ $0.16 \%$ ). The highest polyunsaturated fatty acid was determined as DHA (22:6) with the range of $4.58+-$ $2.44-19.25+-0.09 \%$. The highest and lowest values were observed in the BDE and SC groups, respectively $(P<0.05) . \mathrm{n}-6 / \mathrm{n}-3$ was in the range of $0.06+-0.00-0.09+-0.00$ and the highest PUFA and $\mathrm{n}-3$ was in the BDE group with $20.87 \pm 0.04 \%$ and $19.53 \pm 0.09 \%$, respectively. The lowest PUFA and n-3 was also in the SC group with $4.91 \pm 0.23$ and $4.58 \pm 2.44 \%$, respectively. SFA and MUFA were in the range of 67.08 $\pm 0.16 \%-85.82 \pm 3.90 \%$ and $7.38 \pm 0.01-10.53 \pm 0.02 \%$, respectively. The highest PUFAs were obtained in the BD groups, and the highest PUFA in the BDE group was statistically different from the other groups. PUFA/SFA was detected in the range of $0.06 \pm 0.03-0.31 \pm 0.00$ in the lipid extraction groups.

Table 1 Fatty acid results of Bligh and Dyer groups

\begin{tabular}{|c|c|c|c|c|c|}
\hline & $\mathrm{BDC}$ & BDOS & $\mathrm{BDE}$ & $\mathrm{BDHCl}$ & BDUH \\
\hline $6: 0$ & $0.03 \pm 0.00$ & $0.02 \pm 0.00$ & $0.04 \pm 0.00$ & $0.02 \pm 0.00$ & $*$ \\
\hline $8: 0$ & $0.06 \pm 0.00$ & $0.06 \pm 0.00$ & $0.08 \pm 0.01$ & $0.04 \pm 0.00$ & $0.05 \pm 0.00$ \\
\hline 10:0 & $0.05 \pm 0.04$ & $0.08 \pm 0.00$ & $0.08 \pm 0.00$ & $0.02 \pm 0.01$ & $0.05 \pm 0.01$ \\
\hline 11:0 & $0.02 \pm 0.00$ & $*$ & $0.02 \pm 0.00$ & $0.02 \pm 0.00$ & $*$ \\
\hline $12: 0$ & $0.20 \pm 0.00$ & $0.18 \pm 0.01$ & $0.21 \pm 0.01$ & $0.22 \pm 0.01$ & $0.18 \pm 0.00$ \\
\hline 13:0 & $0.17 \pm 0.00$ & $0.16 \pm 0.01$ & $0.17 \pm 0.01$ & $0.16 \pm 0.00$ & $0.16 \pm 0.01$ \\
\hline 14:0 & $4.37 \pm 0.03$ & $4.16 \pm 0.01$ & $4.44 \pm 0.04$ & $4.37 \pm 0.01$ & $4.31 \pm 0.01$ \\
\hline $15: 0$ & $0.04 \pm 0.01$ & $0.03 \pm 0.00$ & $0.03 \pm 0.00$ & $0.03 \pm 0.01$ & $*$ \\
\hline $16: 0$ & $57.10 \pm 0.58^{\mathrm{b}}$ & $55.78 \pm 0.2^{\mathrm{d}}$ & $57.68 \pm 0.0^{\mathrm{a}}$ & $56.31 \pm 0.0^{\mathrm{c}}$ & $57.43 \pm 0.21^{\mathrm{b}}$ \\
\hline $17: 0$ & $1.40 \pm 0.01^{\mathrm{a}}$ & $1.35 \pm 0.01^{\mathrm{a}}$ & $1.38 \pm 0.01^{\mathrm{a}}$ & $1.37 \pm 0.01^{\mathrm{a}}$ & $0.78 \pm 0.83^{\mathrm{b}}$ \\
\hline 18:0 & $1.99 \pm 0.01^{\mathrm{b}}$ & $2.25 \pm 0.04^{\mathrm{a}}$ & $1.95 \pm 0.11^{\mathrm{b}}$ & $2.15 \pm 0.03^{\mathrm{ab}}$ & $2.26 \pm 0.01^{\mathrm{a}}$ \\
\hline 20:0 & $0.32 \pm 0.00$ & $0.33 \pm 0.00$ & $0.32 \pm 0.00$ & $0.33 \pm 0.00$ & $0.32 \pm 0.00$ \\
\hline 22:0 & $0.10 \pm 0.00$ & $0.11 \pm 0.02$ & $0.11 \pm 0.00$ & $0.11 \pm 0.00$ & $*$ \\
\hline 24:0 & $3.44 \pm 0.06$ & $3.52 \pm 0.06$ & $3.61 \pm 0.02$ & $3.24 \pm 0.00$ & $3.25 \pm 0.04$ \\
\hline SFA & $69.27 \pm 0.56^{\mathrm{b}}$ & $68.01 \pm 0.25^{\mathrm{c}}$ & $70.10 \pm 0.1^{\mathrm{a}}$ & $68.37 \pm 0.11^{\mathrm{c}}$ & $68.77 \pm 0.62^{\mathrm{c}}$ \\
\hline $14: 1$ & $5.00 \pm 0.00$ & $4.70 \pm 0.08$ & $5.06 \pm 0.02$ & $4.73 \pm 0.01$ & $4.78 \pm 0.01$ \\
\hline $15: 1$ & $*$ & $*$ & $*$ & $0.02 \pm 0.00^{\mathrm{a}}$ & $*$ \\
\hline $16: 1$ & $0.52 \pm 0.00$ & $0.61 \pm 0.01$ & $0.40 \pm 0.01$ & $0.05 \pm 0.01$ & $0.62 \pm 0.01$ \\
\hline $18: 1 n-9 t$ & $0.11 \pm 0.00$ & $0.12 \pm 0.01$ & $0.11 \pm 0.00$ & $0.12 \pm 0.00$ & $0.10 \pm 0.00$ \\
\hline $18: 1 n-9 c$ & $2.81 \pm 0.01^{\mathrm{c}}$ & $3.95 \pm 0.08^{\mathrm{b}}$ & $1.66 \pm 0.03^{\mathrm{d}}$ & $4.30 \pm 0.01^{\mathrm{a}}$ & $4.00 \pm 0.01^{\mathrm{b}}$ \\
\hline $20: 1 n-9$ & $0.19 \pm 0.00^{\mathrm{a}}$ & $0.25 \pm 0.00^{\mathrm{a}}$ & $0.10 \pm 0.00^{\mathrm{b}}$ & $0.26 \pm 0.00^{\mathrm{a}}$ & $0.27 \pm 0.01^{\mathrm{a}}$ \\
\hline $22: 1 n-9$ & $0.05 \pm 0.00$ & $0.06 \pm 0.01$ & $0.06 \pm 0.01$ & $0.05 \pm 0.01$ & $0.10 \pm 0.02$ \\
\hline MUFA & $8.68 \pm 0.01^{b}$ & $9.68 \pm 0.18^{\mathrm{a}}$ & $7.38 \pm 0.01^{\mathrm{c}}$ & $9.52 \pm 0.01^{\mathrm{a}}$ & $9.85 \pm 0.03^{\mathrm{a}}$ \\
\hline $18: 2 n-6 t$ & $0.07 \pm 0.00$ & $0.07 \pm 0.00$ & $0.07 \pm 0.00$ & $0.09 \pm 0.01$ & $0.08 \pm 0.01$ \\
\hline $18: 2 n-6 c$ & $0.83 \pm 0.01^{\mathrm{b}}$ & $1.05 \pm 0.03^{\mathrm{a}}$ & $0.65 \pm 0.06^{\mathrm{b}}$ & $1.05 \pm 0.00^{\mathrm{a}}$ & $1.09 \pm 0.02^{\mathrm{a}}$ \\
\hline 20:3n6 & $0.30 \pm 0.00$ & $0.31 \pm 0.01$ & $0.31 \pm 0.00$ & $0.30 \pm 0.00$ & $0.31 \pm 0.01$ \\
\hline $20: 4 n-6$ & $0.19 \pm 0.01$ & $*$ & $0.20 \pm 0.00$ & $0.03 \pm 0.00$ & $0.16 \pm 0.04$ \\
\hline $20: 5 n-3$ & $0.28 \pm 0.01$ & $0.28 \pm 0.00$ & $0.28 \pm 0.00$ & $0.25 \pm 0.00$ & $0.26 \pm 0.00$ \\
\hline $22: 2$ & $0.13 \pm 0.01$ & $0.14 \pm 0.01$ & $0.11 \pm 0.00$ & $0.14 \pm 0.01$ & $0.12 \pm 0.01$ \\
\hline $22: 6 n-3$ & $18.41 \pm 0.20^{\mathrm{b}}$ & $18.52 \pm 0.03^{b}$ & $19.25 \pm 0.09^{\mathrm{a}}$ & $17.50 \pm 0.00^{\mathrm{c}}$ & $17.29 \pm 0.23^{\mathrm{c}}$ \\
\hline PUFA & $20.19 \pm 0.23^{b}$ & $20.37 \pm 0.03^{b}$ & $20.87 \pm 0.00^{\mathrm{a}}$ & $19.35 \pm 0.00^{\mathrm{c}}$ & $19.29 \pm 0.30^{\mathrm{c}}$ \\
\hline n-3 & $18.69 \pm 0.21^{\mathrm{b}}$ & $18.80 \pm 0.03^{b}$ & $19.53 \pm 0.00^{\mathrm{a}}$ & $17.75 \pm 0.00^{\mathrm{c}}$ & $17.55 \pm 0.23^{\mathrm{c}}$ \\
\hline n-6 & $1.38 \pm 0.01^{\mathrm{b}}$ & $1.43 \pm 0.01^{\mathrm{b}}$ & $1.23 \pm 0.06^{\mathrm{c}}$ & $1.47 \pm 0.01^{\mathrm{b}}$ & $1.63 \pm 0.06^{\mathrm{a}}$ \\
\hline$n-9$ & $3.16 \pm 0.01^{\mathrm{b}}$ & $4.37 \pm 0.08^{\mathrm{a}}$ & $1.93 \pm 0.02^{\mathrm{c}}$ & $4.72 \pm 0.01^{\mathrm{a}}$ & $4.46 \pm 0.01^{\mathrm{a}}$ \\
\hline$n-6 / n-3$ & $0.07 \pm 0.00^{\mathrm{c}}$ & $0.08 \pm 0.00^{\mathrm{b}}$ & $0.06 \pm 0.00^{\mathrm{d}}$ & $0.08 \pm 0.00^{\mathrm{b}}$ & $0.09 \pm 0.00^{\mathrm{a}}$ \\
\hline PUFA/SFA & $0.29 \pm 0.01^{\mathrm{ab}}$ & $0.30 \pm 0.01^{\mathrm{a}}$ & $0.30 \pm 0.01^{\mathrm{a}}$ & $0.28 \pm 0.00^{\mathrm{b}}$ & $0.28 \pm 0.01^{\mathrm{b}}$ \\
\hline
\end{tabular}


*Non-detected

Data are expressed as the mean $\pm \mathrm{SD}$. The lower case letters show the statistical difference between cell disruption methods $(P<0.05)$.

Table 2 Fatty acid results of Soxhlet groups

\begin{tabular}{|c|c|c|c|c|c|}
\hline & $\mathrm{SC}$ & SOS & SE & SHCl & SUH \\
\hline 10:0 & $*$ & $*$ & * & $0.03 \pm 0.01^{\mathrm{a}}$ & $*$ \\
\hline 11:0 & $*$ & * & * & $0.03 \pm 0.01^{\mathrm{a}}$ & * \\
\hline 12:0 & $0.23 \pm 0.01^{\mathrm{b}}$ & $0.70 \pm 0.46^{\mathrm{a}}$ & $*$ & $0.20 \pm 0.00^{\mathrm{b}}$ & $0.23 \pm 0.01^{\mathrm{b}}$ \\
\hline 13:0 & $0.23 \pm 0.09^{\mathrm{b}}$ & $0.56 \pm 0.25^{\mathrm{a}}$ & * & $0.16 \pm 0.00^{\mathrm{b}}$ & $0.18 \pm 0.01^{\mathrm{b}}$ \\
\hline 14:0 & $5.55 \pm 0.15^{\mathrm{a}}$ & $4.29 \pm 0.75^{\mathrm{c}}$ & $4.91 \pm 0.19^{\mathrm{b}}$ & $4.33 \pm 0.05^{\mathrm{c}}$ & $4.60 \pm 0.04^{\mathrm{bc}}$ \\
\hline 15:0 & & $*$ & & $0.03 \pm 0.00^{\mathrm{a}}$ & \\
\hline 16:0 & $74.86 \pm 2.88^{\mathrm{a}}$ & $60.62 \pm 2.16^{\mathrm{c}}$ & $62.42 \pm 1.29^{\mathrm{b}}$ & $54.90 \pm 0.17^{\mathrm{d}}$ & $60.24 \pm 0.23^{\mathrm{c}}$ \\
\hline 17:0 & $0.99 \pm 1.07^{\mathrm{d}}$ & $1.23 \pm 0.33^{\mathrm{c}}$ & $1.40 \pm 0.12^{\mathrm{a}}$ & $1.34 \pm 0.01^{\mathrm{bc}}$ & $1.40 \pm 0.00^{\mathrm{a}}$ \\
\hline 18:0 & $2.68 \pm 0.05^{\mathrm{b}}$ & $2.52 \pm 0.58^{\mathrm{b}}$ & $3.28 \pm 0.39^{\mathrm{a}}$ & $2.19 \pm 0.03^{\mathrm{c}}$ & $2.07 \pm 0.05^{\mathrm{c}}$ \\
\hline 20:0 & $0.41 \pm 0.08^{\mathrm{a}}$ & $*$ & $*$ & $0.32 \pm 0.03^{\mathrm{a}}$ & $0.31 \pm 0.01^{\mathrm{a}}$ \\
\hline 22:0 & $*$ & $*$ & $*$ & $0.06 \pm 0.03^{\mathrm{a}}$ & $*$ \\
\hline 24:0 & $0.90 \pm 0.42^{\mathrm{c}}$ & $2.60 \pm 0.08^{\mathrm{b}}$ & $3.16 \pm 0.79^{\mathrm{a}}$ & $3.51 \pm 0.02^{\mathrm{a}}$ & $3.33 \pm 0.01^{\mathrm{a}}$ \\
\hline SFA & $85.82 \pm 3.90^{\mathrm{a}}$ & $72.51 \pm 4.44^{\mathrm{d}}$ & $77.56 \pm 2.01^{\mathrm{b}}$ & $67.08 \pm 0.16^{\mathrm{d}}$ & $72.34 \pm 0.19^{c}$ \\
\hline 14:1 & $5.86 \pm 0.16^{\mathrm{a}}$ & $4.29 \pm 0.95^{\mathrm{d}}$ & $5.11 \pm 0.19^{\mathrm{b}}$ & $4.73 \pm 0.01^{\mathrm{c}}$ & $5.12 \pm 0.06^{\mathrm{b}}$ \\
\hline 15:1 & $*$ & $*$ & $*$ & $0.03 \pm 0.01^{\mathrm{a}}$ & \\
\hline 16:1 & $0.37 \pm 0.02^{\mathrm{b}}$ & $0.69 \pm 0.34^{\mathrm{a}}$ & $*$ & $0.63 \pm 0.00^{\mathrm{a}}$ & $0.40 \pm 0.01^{\mathrm{b}}$ \\
\hline 18:1n-9t & $*$ & $*$ & $*$ & $0.12 \pm 0.00^{\mathrm{a}}$ & $0.11 \pm 0.01^{\mathrm{a}}$ \\
\hline 18:1n-9c & $1.75 \pm 0.11^{\mathrm{e}}$ & $3.13 \pm 0.69^{\mathrm{b}}$ & $2.63 \pm 0.74^{\mathrm{c}}$ & $4.68 \pm 0.01^{\mathrm{a}}$ & $2.23 \pm 0.14^{\mathrm{d}}$ \\
\hline 20:1n-9 & $*$ & $*$ & $*$ & $0.28 \pm 0.00^{\mathrm{a}}$ & $0.14 \pm 0.01^{\mathrm{b}}$ \\
\hline $22: 1 n-9$ & $*$ & $*$ & $*$ & $0.06 \pm 0.00^{\mathrm{a}}$ & $*$ \\
\hline MUFA & $7.97 \pm 0.03^{\mathrm{b}}$ & $8.10 \pm 1.98^{\mathrm{b}}$ & $7.74 \pm 0.55^{\mathrm{b}}$ & $10.53 \pm 0.02^{\mathrm{a}}$ & $7.99 \pm 0.08^{b}$ \\
\hline $18: 2 n-6 t$ & $*$ & $*$ & $*$ & $0.08 \pm 0.01^{\mathrm{b}}$ & $0.32 \pm 0.00^{\mathrm{a}}$ \\
\hline $18: 2 n-6 c$ & $0.33 \pm 0.07^{\mathrm{d}}$ & $0.98 \pm 0.52^{\mathrm{b}}$ & $*$ & $1.21 \pm 0.01^{\mathrm{a}}$ & $0.60 \pm 0.02^{\mathrm{c}}$ \\
\hline $20: 3 n-6$ & $*$ & $*$ & $*$ & $0.31 \pm 0.00^{\mathrm{a}}$ & $0.32 \pm 0.00^{\mathrm{a}}$ \\
\hline $20: 4 n-6$ & $*$ & $*$ & $*$ & $0.20 \pm 0.00^{\mathrm{a}}$ & $*$ \\
\hline $20: 5 n-3$ & $*$ & $*$ & $*$ & $0.28 \pm 0.00^{\mathrm{a}}$ & $0.26 \pm 0.01^{\mathrm{a}}$ \\
\hline $22: 2$ & $*$ & $*$ & $*$ & $0.13 \pm 0.00^{\mathrm{a}}$ & $*$ \\
\hline $22: 6 n-3$ & $4.58 \pm 2.44^{\mathrm{d}}$ & $13.33 \pm 0.25^{\mathrm{c}}$ & $13.13 \pm 0.02^{\mathrm{c}}$ & $18.64 \pm 0.05^{\mathrm{a}}$ & $17.45 \pm 0.11^{\mathrm{b}}$ \\
\hline PUFA & $4.91 \pm 0.23^{\mathrm{e}}$ & $14.30 \pm 0.76^{\mathrm{c}}$ & $13.13 \pm 0.02^{\mathrm{d}}$ & $20.84 \pm 0.05^{\mathrm{a}}$ & $18.94 \pm 0.13^{\mathrm{b}}$ \\
\hline n-3 & $4.58 \pm 2.44^{\mathrm{d}}$ & $13.33 \pm 0.25^{\mathrm{c}}$ & $13.13 \pm 0.02^{\mathrm{c}}$ & $18.92 \pm 0.05^{\mathrm{a}}$ & $17.70 \pm 0.11^{\mathrm{b}}$ \\
\hline n-6 & $0.33 \pm 0.07^{\mathrm{d}}$ & $0.98 \pm 0.52^{\mathrm{c}}$ & $*$ & $1.79 \pm 0.00^{\mathrm{a}}$ & $1.24 \pm 0.02^{\mathrm{b}}$ \\
\hline n-9 & $1.75 \pm 0.11^{\mathrm{d}}$ & $3.13 \pm 0.69^{\mathrm{b}}$ & $2.63 \pm 0.74^{\mathrm{c}}$ & $5.14 \pm 0.01^{\mathrm{a}}$ & $2.48 \pm 0.13^{\mathrm{c}}$ \\
\hline$n-6 / n-3$ & $0.08 \pm 0.03^{\mathrm{b}}$ & $0.07 \pm 0.04^{\mathrm{b}}$ & $*$ & $0.09 \pm 0.00^{\mathrm{a}}$ & $0.07 \pm 0.00^{b}$ \\
\hline PUFA/SFA & $0.06 \pm 0.03^{\mathrm{d}}$ & $0.20 \pm 0.00^{\mathrm{c}}$ & $0.19 \pm 0.00^{\mathrm{c}}$ & $0.31 \pm 0.00^{\mathrm{a}}$ & $0.26 \pm 0.00^{\mathrm{a}}$ \\
\hline
\end{tabular}

*Non-detected

Data are expressed as the mean \pm SD. The lower-case letters show the statistical difference between cell disruption methods $(P<0.05)$.

According to the results of fatty acids, there were not significant differences in the cell disruption groups compared to the control groups. Among the total crude lipid methods, Bligh and Dyer showed better results in terms of fatty acids. It was thought that the temperature applied in Soxhlet damaged the lipid material. Lower fatty acid amounts were obtained in all Soxhlet applied groups. It also appears that Soxhlet 
method damaged to DHA. In the study by Guckert et al. (1988) on lipid solvent system for the analysis of lipid classes inChlorella, Bligh and Dyer provided the most quantitative and reproducible recovery of all Chlorella lipid classes, also, degradation of the polyunsaturated fatty acids was observed during the Soxhlet procedure, similar with our study. Tang et al. (2011) in their study on supercritical $\mathrm{CO}_{2}$ and Soxhlet extraction of lipids and enrichment of DHA from oil-rich microalgaeSchizochytrium limacinum, DHA content was obtained in these groups as $27.5 \%$ and $15.4 \%$, respectively. It was concluded supercritical $\mathrm{CO}_{2}$ extraction exhibits many advantages over the Soxhlet extraction for the DHA enrichment and purity. In our study, cell disruption methods, particularly osmotic shock, enzyme and $\mathrm{HCl}$ resulted in high yields of saturated fatty acids, monounsaturated fatty acids and polyunsaturated fatty acids in the extracted oil. The highest DHA was detected in the BDE group. The enzymatic hydrolysis was shown to be an effective and nontoxic procedure for improving of extraction efficiency of intracellular compounds (Zhang et al., 2019). Gomes et al. (2020) reported that the microbial cell disruption using enzymes is a promising and highly energy-efficient technology. Furthermore, enzymatic lysis process is considered to be more environmentally friendly (Lee et al., 2017). Taher et al. (2014) in the study on extracting lipid with enzyme (lysozyme and cellulase) and acid treatment from Scenedesmus sp., reported C16:0 as the major saturated fatty acid which was $16.4 \pm 0.08 \%$, $11.9 \pm 0.3 \%$ and $15.1 \pm 0.2 \%$ in the enzyme lysozyme and cellulase, and acid treatments, respectively. Total fatty acids were $84.3 \%, 76.9 \%, 79.7 \%, 82.2 \%$ and $79.0 \%$, in the groups of untreated freeze-dried algae, acid treatment, lysozyme and cellulase enzyme, respectively. Treatments decreased the total fatty acids compared with untreated algae, especially in the acid applied group. Yu et al. (2015) in their study investigating the effect of autoclaving, bead-beating, microwaving, sonication, acid $(\mathrm{HCl})$ digestion, and Soxhlet extraction to lipid extraction from Chlorella sorokiniana, declared that in Soxhlet method saturated fatty acids 16:0 and 18:0 were affected, and lower results were obtained compared with other methods. In autoclaving and microwaving methods, 16:1, 18:0, 18:2 and 18:3 were not obtained when these fatty acids were relatively high in $\mathrm{HCl}$ digestion, especially for $18: 2$ with $28.9 \pm 1.4 \%$. In our study, most of fatty acids were obtained with $\mathrm{HCl}$ digestion. Although $\mathrm{HCl}$ that was reported to cause harm in the literature, did not cause any loss in fatty acids in our study. But Taher et al. (2014) reported that using acids requires special materials of construction, which is not economic for large-scale applications. Safety issues, and wastewater treatment are also essential for strong acid treatment (Lee et al., 2017) and it is thought that the method will not be safe in applications such as feed, food and cosmetics. In our study, effective results were obtained in terms of fatty acids in the OS and UH groups with the BD method. In the study by Prabakaran and Ravindran (2011) on cell disruption methods (autoclaving, bead beating, microwave, sonication, $10 \% \mathrm{NaCl}$ solution) for lipid extraction fromChlorella sp., Nostoc sp. and Tolypothrix sp. sonication was found as the most effective method. Osmotic shock has advantages such as; lower energy consumption, easier scale-up, faster extractionsuitable for all cell types, however it has disadvantages like generation of waste salt water, salt's high cost (Lee et al., 2017) time consuming. Sonication also has disadvantages such as damaging chemical structure of molecules (Byreddy et al., 2015).

In the present study, palmitic acid and DHA constitute most of the total fatty acids. It is an expected result that palmitic is high in aquatic plants, and the high amount of DHA, as a valuable fatty acid in terms of human health, is an important criterion. High DHA adds value to our product. It is thought that the evaluation of this algae for use in areas such as food and feed will make an important contribution. Ju et al. (2020) in their study the resulting microalgal lipids are mainly docosahexaenoic acid (DHA) and palmitic acid, also they reported palmitic acid is a saturated fatty acid (SFA) that is used as an emollient and diluent in the cosmetics industry. Fedorova-Dahms et al. (2011) reported that Schizochytrium sp. oil contains 40-45\% DHA and up to 10\% EPA. Leaño et al. (2003) found the amount of lipid in the range of 13.0-39.1\%, in their studies of growth and fatty acid production of Schizochytrium sp. at different salinity and temperatures. In the study by Li et al. (2009) on was usedSchizochytrium as supplements in Ictalurus punctatus feed, the highest PUFA in dry algae was determined as DHA with $31.39 \%$ and n-3 PUFA was $37.08 \%$. It was concluded that addition of $2 \%$ dried algae in the diet markedly improves the levels of 22:6 n-3 and n-3 LC-PUFAs in the edible tissue of fish. DHA and palmitic acid were high in $\%$ total fatty acids similar with our study. In our study; SFA, MUFA and PUFA were obtained in the range of $67.08-85.82 \%, 7.38-10.53 \%$, and $4.91-20.87 \%$, respectively. In the study of Byreddy et al. (2015) saturated, monounsaturated and polyunsaturated fatty 
acids were obtained in the range of $49 \%-57 \%, 31 \%-35 \%$ and $2 \%-18 \%$, respectively forSchizochytrium sp.. PUFA obtained in our study higher than that reported by Byreddy et al. (2015). n-3 FAs have beneficial effects against chronic metabolic diseases, such as obesity, diabetes, and cardiovascular diseases, different cancers, asthma, inflammatory bowel disease, rheumatoid arthritis, psoriasis and osteoporosis (Prato et al., 2019). Because of their health benefits of long-chain n-3 polyunsaturated fatty acids, especially DHA, consumer preference increased for the products fortified with these desirable nutrients (Liu et al., 2020). n-3, n-6 and n-3/n-6, DHA/EPA, PUFA/SFA, unsaturated (UNS)/SFA ratios are widely used to evaluate the nutritional value of lipid (Prato et al., 2019). In our present study n-3 and n- 6 were detected between 4.58 $\pm 2.44-19.53 \pm 0.09 \%$ and $0.33 \pm 0.07-1.79 \pm 0.00 \%$, respectively. $\mathrm{n}-6 / \mathrm{n}-3$ ratio was detected in the range of $0.06 \pm 0.00-0.09 \pm 0.09$. Gonçalves et al. (2021) reported that $\mathrm{n}-6 / \mathrm{n}-3$ ratio below 4.0 in a diet indicates desirable quantities for human health. In our study, this ratio was below the limits that Gonçalves et al. (2021) reported, in our study. Increasing consumption of fish and fish products rich in n-3 PUFA (polyunsaturated fatty acids), which is important for human health, and poor in n-6 PUFA, should be encouraged (Metin et al., 2021). PUFA/SFA ratio was obtained between $0.06 \pm 0.03-0.31 \pm 0.00$ values. Due to the high content of palmitic acid, this ratio was obtained at low levels. However, the values were close to the minimum limit value of 0.45 specified by Gonçalves et al. (2021) and Liu et al. (2020) except for the SC group.

As a result; as Zhang et al. (2019) reported; compared with conventional methods, the use of emerging techniques allowed the recovery bio-molecules avoiding toxic solvent, high temperature and treatment time.

\section{Lipids nutritional quality indices (LNQI)}

In the different total crude lipid and cell disruption methods applied groups, atherogenicity index (AI) was detected in the range of $2.31 \pm 0.00-7.72 \pm 1.76$. The highest and lowest values were observed in the $\mathrm{SC}$ and $\mathrm{SHCl}$ groups, respectively. In the other groups, this value was found to be between $2.42 \pm$ 0.02-3.94 \pm 0.21 . Thrombogenicity index (TI) was found in the range of $0.74 \pm 0.00-2.70 \pm 1.15$. The lowest value was detected in the BDOS and $\mathrm{SHCl}$ and the highest value was in the group SOS. Fatty acids hypocholesterolemic/hypercholesterolemic ratios $(\mathrm{HH})$ were in the range of $0.08 \pm 0.04-0.42 \pm 0.00$, the highest value was found in $\mathrm{SHCl}$ and the lowest value was in the group SC (Table 3).

Table 3 Lipids nutritional quality indices results

\begin{tabular}{|c|c|c|c|c|c|c|c|c|c|c|}
\hline & BDC & $\mathrm{SC}$ & BDOS & SOS & BDE & SE & $\mathrm{BDHCl}$ & SHCl & BDUH & SU \\
\hline $\mathrm{AI}$ & $2.59 \pm 0.04$ & $7.72 \pm 1.76$ & $2.42 \pm 0.02$ & $3.51 \pm 0.18$ & $2.68 \pm 0.01$ & $3.94 \pm 0.21$ & $2.56 \pm 0.00$ & $2.31 \pm 0.00$ & $2.57 \pm 0.02$ & \\
\hline TI & $0.76 \pm 0.01$ & $2.70 \pm 1.15$ & $0.74 \pm 0.02$ & $1.01 \pm 0.14$ & $0.72 \pm 0.10$ & $*$ & $0.79 \pm 0.00$ & $0.74 \pm 0.00$ & $0.82 \pm 0.00$ & \\
\hline $\mathrm{HH}$ & $0.37 \pm 0.01$ & $0.08 \pm 0.04$ & $0.40 \pm 0.01$ & $0.27 \pm 0.01$ & $0.35 \pm 0.00$ & $0.23 \pm 0 \quad 02$ & $0.38 \pm 0.00$ & $0.42 \pm 0.00$ & $0.37 \pm 0.00$ & \\
\hline
\end{tabular}

*Could not be calculated since n- 6 was not found.

Prato et al. (2019) reported that Atherogenic index (AI), thrombogenicity index (TI) and hypocholesterole$\mathrm{mic} /$ hypercholesterolemic fatty acid ratio $(\mathrm{HH})$ provide indications on the dietetic quality of lipids and their potential effect on the development of coronary disease. They found AI and TI below 1 in edible marine bivalves. In the groups of cell disruption methods in our study, TI was detected below 1, except in the group SOS. Hypocholesterolemic/hypercholesterolemic fatty acid ratios $(\mathrm{HH})$ were found between 0.08-0.42. High hypocholesterolemic/hypercholesterolemic fatty acid ratio (HH) is desirable. Prato et al. (2019) was found this index between 0.25-3.23 and qualified as high. In our study AI was slightly higher, in fact, between 2-3 values, but it was detected as 7.55 only in the SC group. Aussant et al. (2018) in the study of fatty acid composition and nutritional value in eight species of microalgae, found the lowest HI (0.597) in N. salina . AI values were between 0.434-1.323, and TI results were 0.189-0.676. In our study, the lowest TI was found in BD groups by associating with DHA values. Concerning HI somewhat low, AI values were average and TI values were also low. Relatively high HI, low AI and TI values are desirable for healthy diet (Aussant et al., 2018; Liu et al., 2020). In our study, it is thought that the relatively low HI and average AI values are caused by high 16:0. 


\section{Conclusions}

In the study of total crude lipid methods combined with cell disruption applications to increase lipid yield of Schizochytrium sp., Bligh and Dyer method was found to be more applicable than Soxhlet. According to the results, Schizochytrium sp. is the best source of DHA essential fatty acid. Higher amount of DHA that is necessary for human health, is advantageous to be used in many applications such as food, feed and cosmetics. Total lipit and fatty acids were found higher than Soxhlet in Bligh and Dyer groups. Soxhlet method can be good at lipid extraction, however damages fatty acids. Lipid health indices such as n-6/n-3, PUFA/SFA, AI, TI and HH were almost favorable. To get higher lipid yield and quality from algal cells, a suitable cell disruption method is required. The enzyme application combined with Bligh and Dyer method is thought to give the most efficient result, with being high-efficiency, environmentally friendly, non-toxic and industrial scale feasibility. As a recommendation, combined cell disruption methods can be used in future studies.

\section{Acknowledgements}

The study was supported by a grant from the Scientific Research Projects Coordination Unit of Muğla Sitkı Koçman University (19/080/01/2/6). The authors wish to thank Marin Biotechnology Products and Food Industry (Aydin/Turkey) for providing the samples.

\section{References}

AOAC (2005). Official methods of analysis of AOAC International, Method 960.39 and 948.22, 18th Ed., AOAC International, Gaithersburg, MD.

AOAC (2006). Crude fat determination-Soxhlet method. Meat technology information sheet, 1-3.

Araujo, G. S., Matos, L. J. B. L., Fernandes, J. O., Cartaxo, S. J. M., Gonçalves, L. R. B., Fernandes, F. A. N., \& Farias, W. R. L. (2013). Extraction of lipids from microalgae by ultrasound application: Prospection of the optimal extraction method. Ultrasonics Sonochemistry,20: 95-98. https://doi.org/10.1016/j.ultsonch.2012.07.027

Aussant, J., Guihéneuf, F., \& Stengel, D. B. (2018). Impact of temperature on fatty acid composition and nutritional value in eight species of microalgae. Applied Microbiology and Biotechnology,102: 5279-5297. https://doi.org/10.1007/s00253-018-9001-x

Bligh, E. G., \& Dyer, W. J. (1959). A rapid method of total lipid extraction and purification. Canadian Journal of Biochemistry and Physiology, 37: 911-917. https://doi.org/10.1139/o59-099

Borowitzka, M. A. (2013). High-value products from microalgae - their development and commercialisation. Journal of Applied Phycology,25: 743-756. https://doi.org/10.1007/s10811-013-9983-9

Byreddy, A. R., Gupta, A., Barrow, C. J., \& Puri, M. (2015). Comparison of cell disruption methods for improving lipid extraction from thraustochytrid strains. Marine Drugs, 13: 5111-5127. https://doi.org/10.3390/md13085111

Chang, M., Zhang, T., Guo, X., Liu, Y., Liu, R., Jin, Q., \& Wang, X. (2020). Optimization of cultivation conditions for efficient production of carotenoid rich DHA oil by Schizochytrium sp. S31. Process Biochemistry, 94: 190-197. https://doi.org/10.1016/j.procbio.2020.04.007

Cheng, C., Du, T., Pi, H., Jang, S., Lin, Y., \& Lee, H. (2011). Comparative study of lipid extraction from microalgae by organic solvent and supercritical $\mathrm{CO}_{2}$. Bioresource Technology, 102: 10151-10153. https://doi.org/10.1016/j.biortech.2011.08.064

Cho, H., Oh., Y., Park, S., Lee, J., \& Park, J. (2013). Effects of enzymatic hydrolysis on lipid extraction from Chlorella vulgaris . Renewable Energy, 54: 156-160. https://doi.org/10.1016/j.renene.2012.08.031

Fedorova-Dahms, I., Marone, P. A., Bauter, M., \& Ryan, A. S. (2011). Safety evaluation of 
DHA-rich algal oil from Schizochytrium sp.. Food and Chemical Toxicology, 49: 3310-3318. https://doi.org/10.1016/j.fct.2011.08.024

Gomes, T. A., Zanette, C. M., \& Michele Rigon Spier, M. R. (2020). An overview of cell disruption methods for intracellular biomolecules recovery. Preparative Biochemistry and Biotechnology,50: 635-654. https://doi.org/10.1080/10826068.2020.1728696

Gonçalves, R. M., Petenuci, M. E., Maistrovicz, F. C., Galuch, M. B., Montanher, P. F., Pizzo, F. C., Gualda I. P., \& Visentainer, J. V. (2021). Lipid profile and fatty acid composition of marine fish species from northeast coast of Brazil. Journal of Food Science and Technology,58: 1177-1189. https://doi.org/10.1007/s13197-02004631-y

Halim, R., Harun, R., Danquah, M. K., \& Webley, P. A. (2012). Microalgal cell disruption for biofuel development. Applied Energy,91: 116-121. https://doi.org/10.1016/j.apenergy.2011.08.048

Ichihara, K., Shibahara, A., Yamamoto, K., \& Nakayama, T. (1996). An improved method for rapid analysis of the fatty acids of glycerolipids. Lipids, 31: 535-539. https://doi.org/10.1007/BF02522648

ISO (1990). Animal and vegetable fats and oils-Analysis by gas chromatography of methyl esters of fatty acids. EN ISO 5508.

Ju, J., Ko, D., Heo, S., Lee, J., Kim, Y., Lee, B., Kim, M., Kim, C., Seo, J., \& Oh, B. (2020). Regulation of lipid accumulation using nitrogen for microalgae lipid production in Schizochytrium sp. ABC101. Renewable Energy, 153: 580-587. https://doi.org/10.1016/j.renene.2020.02.047.

Leaño, E. M., Gapasin, R. S. J., Polohan, B., \& Vrijmoed, L. L. P. (2003). Growth and fatty acid production of thraustochytrids from Panay mangroves, Philippines. Fungal Diversity, 12: 111-122. http://hdl.handle.net/10862/1969

Lee, I., \& Han, J. (2015). Simultaneous treatment (cell disruption and lipid extraction) of wet microalgae using hydrodynamic cavitation for enhancing the lipid yield. Bioresource Technology, 186: 246-251. https://doi.org/10.1016/j.biortech.2009.03.058

Lee, S. Y., Cho, J. M., Chang, Y. K., \& Oh, Y. (2017). Cell disruption and lipid extraction for microalgal biorefineries: A review. Bioresource Technology, 244: 1317-1328. http://dx.doi.org/10.1016/j.biortech.2017.06.038

Li, M. H., Robinson, E. H., Tucker, C. S., Manning, B. B., \& Khoo, L. (2009). Effects of dried algae Schizochytrium sp., a rich source of docosahexaenoic acid, on growth, fatty acid composition, and sensory quality of channel catfish Ictalurus punctatus . Aquaculture,292: 232-236. https://doi.org/10.1016/j.aquaculture.2009.04.033

Liang, K., Zhang, Q., \& Cong, W. (2012). Enzyme-assisted aqueous extraction of lipid from microalgae. Journal of Agricultural and Food Chemistry, 60: 11771-11776. https://doi.org/10.1021/jf302836v

Liu, B., Jiang, J., Yu, Lin, G., Xiong, \& Y. L. (2020). Effects of supplementation of microalgae (Aurantiochytrium sp. ) to laying hen diets on fatty acid content, health lipid indices, oxidative stability, and quality attributes of meat. Foods, 9: 1-16. https://doi.org/10.3390/foods9091271

Metin, C., Alparslan, Y., Yapıcı, H. H., Ekşi, Z., \& Baygar, T. (2021). Assessment of the effects of sex and harvesting season on lipid and fatty acid composition of Sparidae species. Lipids, https://doi.org/10.1002/lipd.12300

Mubarak, M., Shaija, A., \& Suchithra, T. V. (2015). A review on the extraction of lipid from microalgae for biodiesel production. Algal Research, 7: 117-123. https://doi.org/10.1016/j.algal.2014.10.008

Nagappan, S., Devendran, S., Tsai, P., Dinakarana, S., Dahms, H., \& Ponnusamyi V. K. (2019). Passive cell disruption lipid extraction methods of microalgae for biofuel production - A review. Fuel,25: 699-709. https://doi.org/10.1016/j.fuel.2019.04.092 
Neto, A. M. P., Souza, R. A. S., Leon-Nino, A. D., Costa, J. D. A, Tiburcio, R. S., Nunes, T. A., Mello, T. C. S., Kanemoto, F. T., Saldanha-Corrêa, F. M. P., \& Gianesella, S. M. F. (2013). Improvement in microalgae lipid extraction using a sonication-assisted method. Renewable Energy, 55: 525-531. https://doi.org/10.1016/j.renene.2013.01.019

Prabakaran, P., \& Ravindran, A. D. (2011). A comparative study on effective cell disruption methods for lipid extraction from microalgae. Letters in Applied Microbiology, 53: 150-154. https://doi.org/10.1111/j.1472765X.2011.03082.x

Prato, E., Biandolino, F., Parlapiano, I., Giandomenico, S., Denti, G., Calò, M., Spada, L., \& Di Leo, A. (2019). Proximate, fatty acids and metals in edible marine bivalves from Italian market: Beneficial and risk for consumers health. Science of the Total Environment,648: 153-163. https://doi.org/10.1016/j.scitotenv.2018.07.382

Ortega-Berlanga B., Banuelos-Hernandez, B., \& Rosales-Mendoza, S. (2018). Efficient expression of an alzheimer's disease vaccine candidate in the microalga Schizochytrium sp. using the algevir system. Molecular Biotechnology, 60: 362-368. https://doi.org/10.1007/s12033-018-0077-4

Souza Silva, A. P. F., Costa, M. C., Lopes, A. C., Neto, E. F. A., Leitao, R. C., Cesar Rossas Mota, \& dos Santos, A.B. (2014). Comparison of pretreatment methods for total lipids extraction from mixed microalgae. Renewable Energy, 63: 762-766. https://doi.org/10.1016/j.renene.2013.10.038

Taher, H., Al-Zuhair, S., Al-Marzouq, A. H., \& Haik, Y. (2014). Effective extraction of microalgae lipids from wet biomass for biodiesel production. Biomass and Bioenergy, 66: 159-167. https://doi.org/10.1016/j.biombioe.2014.02.034

Tang, S., Qin, C., Wang, H., Li, S., \& Tian, S. (2011). Study on supercritical extraction of lipids and enrichment of DHA from oil-rich microalgae. The Journal of Supercritical Fluids, 57: 44-49. https://doi.org/10.1016/j.supflu.2011.01.010

Wang, S., Wang, X., Tian, Y., \& Cui, Y. (2020). Nutrient recovery from tofu whey wastewater for the economical production of docosahexaenoic acid by Schizochytrium sp. S31. Science of the Total Environment,710: 136448. https://doi.org/10.1016/j.scitotenv.2019.136448

Yu, X., Dong, T., Zheng, Y., Miao, C., \& Chen, S. (2015). Investigations on cell disruption of oleaginous microorganisms: Hydrochloric acid digestion is an effective method for lipid extraction. European Journal of Lipid Science and Technology, 117: 730-737. https://doi.org/10.1002/ejlt.201400195

Zhang, Y., Kong, X., Wang, Z., Sun, Y., Zhu, S., Li, L., \& Lv, P. (2018). Optimization of enzymatic hydrolysis for effective lipid extraction from microalgae Scenedesmus sp.. Renewable Energy,125: 10491057. https://doi.org/10.1016/j.renene.2018.01.078

Zhang, R., Parniakov, O., Grimi, N., Lebovka, N., Marchal, L., \& Vorobiev, E. (2019). Emerging techniques for cell disruption and extraction of valuable bio-molecules of microalgaeNannochloropsis sp.. Bioprocess and Biosystems Engineering,42: 173-186. https://doi.org/10.1007/s00449-018-2038-5

\section{Hosted file}

Figures.docx available at https://authorea.com/users/420143/articles/526520-effect-ofdifferent-cell-disruption-methods-on-lipid-yield-of-schizochytrium-sp 